\title{
Content of Capsaicinoids and Physicochemical Characteristics of Manzano Hot Pepper Grown in Greenhouse
}

\author{
Mario PÉREZ-GRAJALES ${ }^{1}$, María T. MARTÍNEZ-DAMIÁN ${ }^{1 *}$, \\ Oscar CRUZ-ALVAREZ ${ }^{2}$, Sandra M. POTRERO-ANDRADE ${ }^{1}$, \\ Aureliano PEÑA-LOMELÍ ${ }^{1}$, Víctor A. GONZÁLEZ-HERNÁNDEZ ${ }^{3}$, \\ Angel VILLEGAS-MONTER ${ }^{3}$
}

\begin{abstract}
${ }^{1}$ Autonomous University Chapingo, Department of Plant Science, Km. 38.5 Mexico-Texcoco Highway, CP 56230 Chapingo, State of Mexico, Mexico; perezgm7@yahoo.com.mx; aplomeli@correo.chapingo.mx; samypoan@hotmail.com; teremd13@gmail.com (*correspondingauthor)

${ }^{2}$ Autonomous University of Chibuahua, Faculty of Agrotechnological Sciences, Pascual Orozco Avenue, Campus 1, Santo Niño, CP 31350 Chibuahua,Mexico;ocruz@uach.mx

${ }^{3}$ Postgraduate College, Campus Montecillo, Texcoco, CP 56230 Montecillo, State of Mexico, Mexico; vagh@colpos.mx; avillega@colpos.mx
\end{abstract}

\begin{abstract}
The hotness of the chili fruit (Capsicum spp.) is mainly due to the presence of capsaicinoids (capsaicin, nordihydrocapsaicin and dihydrocapsaicin). The aim of the present research was to evaluate the content of capsaicinoids and characteristics of physicochemical quality in fruits of manzano hot pepper grown in the greenhouse. The experimental design used was completely randomized with 3 and 4 replications. The parameters evaluated were total capsaicinoids, vitamin $\mathrm{C}$, total carotenoids (TC), total soluble solids (TSS), titratable acidity, $\mathrm{pH}$, firmness and color of the fruit. Among the hybrids with the highest content of total capsaicinoids and vitamin C, L4XL8 and L5XL7 (27 371 and 21700 SHU, respectively) stand out as

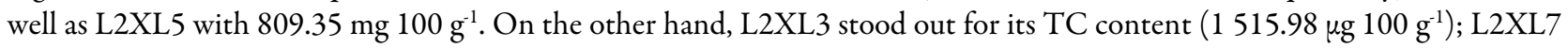
and L4X17 stood out for the concentration of TSS, maintaining the acidity level without major changes. Additionally, L7XL8 was a material that was characterized to have fruits with greater firmness $(2.31 \mathrm{~N})$ and chromaticity of color (intense yellow) of 72.96. Among the evaluated hybrids, there are materials that presented fruits with physical and chemical characteristics of quality, which could be considered important from the commercial point of view or genetic improvement.
\end{abstract}

Keywords: Capsicum pubescens Ruiz y Pavón; color; fruit quality; scoville heat unit; titratable acidity; total carotenoids Abbreviations: Ci: Capsaicin; Dhc: Dihydrocapsaicin; N: Newton's; Nhc: Norhydricapsaicin; TC: Total carotenoids; TCi: Total capsaicinoids; TSS; total soluble solids; TA: Titratable acidity; VC: Vitamin C.

\section{Introduction}

The consumption of products of vegetable origin among the various prehispanic people, according to the Florentino Codex, was basically constituted by corn (Zea mays L.), beans (Phaseolus vulgaris L.), squash (Cucurbita spp.) and chili pepper (Capsicum spp.) (Vera-Guzmán et al., 2011; Meckelmann et al., 2015). The genus Capsicum is composed of 30 species (Agostini-Costa et al., 2017), among them, the domesticated (C. annuum, $C$. baccatum, $C$. chinense, $C$. frutescens and $C$. pubescens), which originated from Mesoamerica (Mexico and Central America) to the Andean region (Ecuador, Bolivia, Chile and Peru), that is, zones with contrasting climatic and tropical characteristics (Rodríguez-Burruezo et al., 2010; Yamamoto et al., 2013). In the particular case of C. pubescens Ruiz and Pavón, its origin goes back to areas with altitudes from 1500 to 3000 masl and temperate climate characteristics in South America (Bolivia, Ecuador and Peru) (Wahyuni et al., 2013; Bo and Carpizo, 2015), where the rest of the species would hardly prosper (Espinosa-Torres and Ramírez-Abarca, 2016).

In Mexico, due to its coloration and morphological characteristics, the fruit of $C$. pubescens is called manzano hot pepper (Espinosa-Torres et al., 2010), and its cultivation is mainly carried out under temporary or backyard conditions, however, in the last decade, its production has 
120

extended to greenhouse conditions, mainly in the temperate zones of Michoacán, Puebla, State of Mexico, Veracruz and to a lesser extent Chiapas and Oaxaca (Espinosa-Torres et al., 2014; Espinosa-Torres and Ramírez-Abarca, 2016), where the use of protected structures allows the incorporation of various technologies such as hydroponics and the control of climatic factors limiting temperature and humidity, which as a whole give the producer an increase in their level of income and productivity of the culture (Pérez and Castro, 1998; Islam et al., 2015), however, due to their physiological and morphological characteristics, prevent proper postharvest handling (Espinosa-Torres et al., 2010) problems that are associated with dehydration, color changes and mechanical damage to the fruit (Vera-Guzmán et al., 2011), as well as a decrease in the expression of characteristics related to its nutritional value (Hwang-Sung et al., 2015).

The intake of chili allows the incorporation into the diet of various bioactive compounds such as anthocyanins, ascorbic acid, phenolic compounds, flavonoids, carotenoids $(\alpha$ - and $\beta$-carotene), capsaicionoids and vitamins (SánchezSánchez et al., 2010; Wahyuni et al., 2013). In this sense, a characteristic that distinguishes the fruits of chili, is the synthesis and accumulation of capsaicinoids, alkaloid group responsible for its pungency (itching), compounds that are located mainly in the tissue of the placenta adjacent to the seeds (Vera-Guzmán et al., 2017), where $90 \%$ is made up of capsaicin, dihydrocapsaicin and nordihydrocapsaicin (Wahyuni et al., 2013; Bo and Carpizo, 2015), whose main function is defense against the attack of mammals (Rodríguez-Burruezo et al., 2010) and the presence of fungi and bacteria (Segura et al., 2013).

There is a great variety of methods of extraction and quantification of capsaicinoids, however, it is common to find among the pungency reports of the various species of Capsicum, values that are expressed by the Scoville (Scoville Heat Units) SHU organoleptic test, and their values they range from 0 for non-pungent varieties (bell pepper) and 2 200000 in chili habanero (C. chinense Jacq.) (Yamamoto et al., 2013; De Aguiar et al., 2016), and in a subjective way it represents a characteristic of nutritional quality which affects its acceptance among consumers. In the case of $C$. pubescens its content varies from 4032 to 60000 SHU (Sánchez-Sánchez et al., 2010). Therefore, the aim of the present research was to evaluate the content of capsaicinoids and characteristics of physicochemical quality in fruits of manzano hot pepper grown in the greenhouse.

\section{Materials and Methods}

\section{Plant material, management and experimental design}

The study involved the use of 25 manzano hot pepper hybrids, obtained as a product of five self-fertilization cycles between eight lines (L1, L2, L3, L4, L5, L6, L7, and L8), as well as the commercial variety 'Grajales St.' (control) (Pérez and Castro, 2012). The cultivation was carried out in greenhouse conditions (double zenithal type and 50\% shade), located in the Experimental Agricultural Field of the Chapingo Autonomous University, State of Mexico (19 $29^{\prime} 23^{\prime \prime} \mathrm{N} ; 98^{\circ} 52^{\prime} 24^{\prime \prime}$ W), 2268 meters above sea level (masl) and average annual temperature of $15.9{ }^{\circ} \mathrm{C}$. The sowing was carried out during the month of November 2011, in trays of polystyrene with 200 cavities and Growing Mix No. 2 as a substrate, to be subsequently transplanted in January 2012. The crop was managed according to a proposed intensive production system by Pérez and Castro (2012), for this, they were placed in white polyethylene bags ( $40 \mathrm{~cm}$ wide and $45 \mathrm{~cm}$ high) in which $50 \%$ course tezontle was used as substrate in the lower part of the bag and a mixture of 25\% Growing Mix No. 2 and 25\% fine tezontle was used in the upper portion. The pots were placed at a distance of $50 \mathrm{~cm}$ between plants and $1 \mathrm{~m}$ between rows. A nebulization and tutoring system was used; For the supply of nutrients, the application of a nutritive solution adapted from Pérez and Castro (1998) was implemented through a drip irrigation system, with an expenditure of $3 \mathrm{~L} / \mathrm{h}$ distributed during the day in three irrigations. The fruits used for the laboratory analysis were harvested in the month of April 2014 and were characterized by presenting average weight of $120 \pm 2 \mathrm{~g}$, intense and uniform yellow color (consumer maturity), where they were visually inspected that they did not present mechanical damage and evidence of damage caused by pests or diseases. The laboratory analyzes were carried out in the Department of Plant Science of the Autonomous University Chapingo. The experimental design was completely randomized with 3 and 4 replicates. The concentration of capsaicionoids consisted of three replicates with 2 fruits per experimental unit. A set of 3 fruits was used as an experimental unit and four replicates for the determination of vitamin C, total carotenoids, total soluble solids, titratable acidity, firmness and fruit color.

\section{Extraction and quantification of capsaicinoids}

Six fruits of each genotype were harvested and placed in ziploc plastic bags $(27 \times 28 \mathrm{~cm})$, transported to the laboratory, where they were lyophilized for 4 days and then homogenized using an Osterizer blender (Cruz-Pérez et al., 2007). The extraction was performed with $1 \mathrm{~g}$ of lyophilized sample, adding $10 \mathrm{~mL}$ of acetonitrile, the mixture was placed in a water bath for 5 hours at $60^{\circ} \mathrm{C}$, a 3 $\mathrm{mL}$ aliquot was taken and filtered through a nylon membrane with pore $45 \mu \mathrm{m}$ and $25 \mathrm{~mm}$ in diameter. The quantification was carried out through the injection of 20 $\mu \mathrm{L}$ of the extract to the Agilent chromatograph model HP1100 equipped with UV detector and Supelcosil LC-18 column $(25 \mathrm{~cm} \times 4.6 \mathrm{~mm}, 5 \mu \mathrm{m})$, whose mobile phase consisted of acetonitrile: water (45:55), $1.5 \mathrm{~mL}$ of flow, 23 $\pm 3{ }^{\circ} \mathrm{C}$ and wavelength of $280 \mathrm{~nm}$. Prior to the calculation of the concentration of total capsaicinoids, the content of individual capsaicinoids was determined by method 995.03 (AOAC, 1995) with the application of the expressions:

$$
\begin{aligned}
& \mathrm{N}=\left[\left(\frac{\mathrm{Pn}}{\mathrm{Ps}}\right) \times\left(\frac{\mathrm{Cs}}{\mathrm{Wt}}\right) \times\left(\frac{10}{0.98}\right)\right] \times 9300 \\
& \mathrm{C}=\left[\left(\frac{\mathrm{Pc}}{\mathrm{Ps}}\right) \times\left(\frac{\mathrm{Cs}}{\mathrm{Wt}}\right) \times\left(\frac{10}{0.89}\right)\right] \times 16100 \\
& \mathrm{D}=\left[\left(\frac{\mathrm{Pd}}{\mathrm{Ps}}\right) \times\left(\frac{\mathrm{Cs}}{\mathrm{Wt}}\right) \times\left(\frac{10}{0.93}\right)\right] \times 16100
\end{aligned}
$$

where:

$\mathrm{N}=$ nordihydrocapsaicin (SHU); C = capsaicin (SHU); D = dihydrocapsaicin (SHU); Pn, Pc, Pd = peak area for nordihydrocapsaicin, capsaicin and dihydrocapsaicin; Ps = 
peak area of the corresponding standard; $\mathrm{Cs}=$ concentration of the standard solution $\left(\mathrm{mg} \cdot \mathrm{mL}^{-1}\right) ; \mathrm{Wt}=$ weight of the sample $(\mathrm{g})$.). The total capsaicinoids were the result of the sum of individual capsaicinoids $(\mathrm{N}+\mathrm{C}+\mathrm{D})$, and $1 \mu \mathrm{g}$ of capsaicinoids $\mathrm{g}^{-1}=15$ Scoville Heat Unit (SHU) (Collins et al., 1995).

\section{Vitamin C (ascorbic acid)}

The determination of the vitamin $\mathrm{C}$ content was carried out according to the method of Tillman (AOAC, 1990) known as DFI-2, 6 dichlorophenol-indophenol, for which the maceration of a sample of pulp was carried out with a stabilizing agent as oxalic acid (to maintain proper acidity for the reaction and avoid self-oxidation of ascorbic acid at high $\mathrm{pH}$ ) and reduction of 2,6-dichlorophenol-indophenol (Tillman's solution). It was estimated from $5 \mathrm{~g}$ of finely chopped fruit and homogenized with $50 \mathrm{~mL}$ of oxalic acid, taking an aliquot of $10 \mathrm{~mL}$. The concentration was expressed in mg $100 \mathrm{~g}^{-1}$ fresh weight by a standard curve of ascorbic acid.

\section{Total carotenoids}

The quantification of carotenoids was carried out according to the technique proposed by Lichtenhaler (1987); a sample of $5 \mathrm{~g}$ of tissue was homogenized with $80 \%$ acetone, the residue was filtered and adjusted to $10 \mathrm{~mL}$, the absorbance reading was obtained at 476, 646 and $663 \mathrm{~nm}$ using the Thermo Scientific Genesys ${ }^{\mathrm{TM}} 10$ UV Scanning spectrophotometer. The content of carotenoids was calculated with the application of the following equations: $\mathrm{Ca}=12.25 \mathrm{~A} 663-2.79 \mathrm{~A} 646 ; \mathrm{Cb}=21.50 \mathrm{~A} 646-5.10$ $\mathrm{A} 663$ and $\mathrm{Cx}+\mathrm{c}=1000 \mathrm{~A} 476-1.82 \mathrm{Ca}-85.02 \mathrm{Cb}$; where: $\mathrm{Ca}=$ chlorophyll $\mathrm{a} ; \mathrm{Cb}=$ chlorophyll $\mathrm{b} ; \mathrm{Cx}+\mathrm{c}=$ total carotenoids; where $\mathrm{A}=$ absorbance reading with different wavelength $(476,646$ and $663 \mathrm{~nm})$. The results were expressed in $\mu \mathrm{g} 100 \mathrm{~g}^{-1}$ fresh weight.

\section{Total soluble solids}

The total soluble solids were quantified with a PAL-1 portable digital refractometer (ATAGO, USA) which uses a scale of $0-53^{\circ}$, and to make the measurement a drop of fruit juice was placed on the refractometer screen to take the reading. The results were expressed in ${ }^{\circ}$ Brix.

\section{Titratable acidity}

The titratable acidity was determined according to the methodology proposed by the AOAC (AOAC, 1990), with $5 \mathrm{~g}$ of pulp that was neutralized with $0.1 \mathrm{~N} \mathrm{NaOH}$, using $1 \%$ phenolphthalein as indicator. The results are reported in $\%$ of citric acid.

\section{Firmness}

The determination of the firmness was made in the equatorial zone of the fruit by means of a Compac Gauge digital penetrometer (Mecmesin", USA) with a cone-shaped strut with a diameter and height of $9 \mathrm{~mm}$, recording the applied force until the penetration of the strut, where the readings were expressed in Newton's $(\mathrm{N})$.

Color

The surface color of the epidermis of the fruit was determined with a Color Tec-PCM ${ }^{\bullet}$ colorimeter (D25PC2 Cole Palmer, USA), recording the initial values of L, a and $b$. With these values the hue angle (hue) and the purity of the color (chroma) were calculated with the formulas: hue $=\arctan \left(b^{*} a^{-1}\right)$; chroma $=\left(a^{2}+b^{2}\right)^{1 / 2} ;$ and the luminosity (L) obtained directly with the device, which corresponds to the color space $\mathrm{L}^{*} \mathrm{a}^{*} \mathrm{~b}$ * (Minolta, 2007).

Statistical analysis

An analysis of variance and Tukey's mean comparison test $(P \leq 0.05)$ were applied to the set of data obtained from each parameter, in which the statistical analysis program Statistical Analysis System was used (SAS), ver. 9.1 (SAS, 2003).

\section{Results and Discussion}

\section{Capsaicinoids}

It is well known that the fruits of the species from the Capsicum genus have different levels of hotness or pungency, and when compared to each other, between the extremes in relation to this characteristic, is the habanero pepper ( $C$. chinense Jacq.) and bell pepper ( $C$. annuum L.) (Figueroa et al., 2015), in which its determination is usually an aspect of important quality among consumers (Wahyuni et al., 2013). As shown in Table 1, the manzano hot pepper showed significant variation $(\mathrm{P} \leq 0.05)$ with respect to the content of total capsaicinoids (level of hotness), which highlights the hybrid L4XL8 with 273706 SHU (Scoville Heat Units), however, L5XL7 presented a statistically similar behavior of $217001 \mathrm{SHU}$, and the contribution of each individual capsaicinoid (norhidrocapsaicin, capsaicin and dihydrocapsaicin) was 21.78, 31.63 and 46.38\%, respectively, this last coincides with that indicated by Orellana-Escobedo et al. (2013) and Meckelmann et al. (2015). Additionally, it is observed that $48 \%$ of the hybrids (L7XL8, L6XL7, L3XL6, L2XL7, L2XL3, L4XL7, L3XL7, L4XL6, L2XL8, L3XL8, L4xL5 and L2XL5) presented values between 127162 and 191459 SHU, which exceeded the commercial variety ('Grajales St.') (126 778 SHU). These results contrast with that observed by Cruz-Pérez et al. (2007) who when evaluating genetic material (progenitors and hybrids) of manzano-pepper with different storage periods, found that fruits with 58 days after flowering showed the maximum values of 55927 and 68 337 SHU, and at day 94, these values decreased to 4472 and 11268 SHU. On the other hand, Sánchez-Sánchez et al. (2010) indicate varieties of manzano hot pepper (Puebla, Huatusco, Zongolica, Peru and Tacámbaro) with a fluctuation between 4032 and 36712 SHU. In other chili species such as $C$. chinense, similar values of 211247.65 SHU are reported (Orellana-Escobedo et al., 2013), as well as De Aguiar et al. (2016) report in 'Naga Jolokia' and 'Murupi' (C. chinense) maximum values of 119016 and 38 910 SHU, respectively, being the first reported value, comparable with the hybrid L1XL7 (119 334) and lower with the obtained in the commercial control. In contrast, Islam et al. (2015) when evaluating the variability in the content of capsaicinoids in chili fruits (Capsicum spp.) (collected and commercial) grown in northeastern India 
report values between 317 and 1152832 SHU. On the other hand, Collins et al. (1995) report values of 216345 SHU for jalapeño pepper ( $C$. annuum L.), which surpasses that reported by Orellana-Escobedo et al. (2013) in nuts of this same type of chili, however, are lower than the maximum values found in this study. The high inter- and intraspecific variation, in relation to the synthesis and concentration of capsaicinoids, can be linked according to Wahyuni et al. (2013) and Rodríguez-Uribe et al. (2014) to the significant effect of the interaction of the fruit with the prevailing environment during the final stages of its growth and development, conditions that are mainly associated with environmental temperature and shading level (Jiménez et al., 2013), as well as to the state of maturity (OrellanaEscobedo et al., 2013) and to the extraction method used (Sánchez-Sánchez et al., 2010).

\section{Vitamin C (ascorbic acid)}

One of the outstanding nutritional characteristics of the chili fruit is its high content of ascorbic acid (Teodoro et al., 2013), in this study it was observed that the L2XL5 hybrid stands out for having the highest content of this vitamin (809.35 mg $100 \mathrm{~g}^{-1}$ ), which represents $40 \%$ more concentration with respect to the materials L2XL7 and L1XL7 (485.75 mg $100 \mathrm{~g}^{-1}$ in both cases) (Table 1). However, it is important to point out that the hybrid L2XL5 presented a similar behavior to that of the majority of the analyzed genotypes (hybrids and commercial variety),

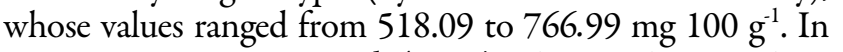
contrast, Cruz-Pérez et al. (2007) when evaluating three hybrids ('Puebla' $\times$ 'Chiapas', 'Puebla' $\times$ 'Huatusco', and 'Puebla' $x$ 'Zongolica') and their progenitors ('Chiapas', 'Puebla', 'Huatusco' and 'Zongolica') with three stages of maturity, found maximum values of $455 \mathrm{mg} 100 \mathrm{~g}^{-1}$, corresponding to the progenitor 'Puebla', with a tendency to present a decrease as the maturation process progresses. Espinoza-Torres et al. (2010) reported values of $230 \mathrm{mg} 100$ $\mathrm{g}^{-1}$ for manzano hot pepper 'Puebla' stored with different packaging and storage temperatures.

On the other hand, Vera-Guzmán et al. (2011) when evaluating a sample of nine regional varieties or chili morphotypes collected in Oaxaca, Mexico; among them

Table 1. Content of capsaicinoids evaluated in manzano hot pepper fruits grown in greenhouse

\begin{tabular}{|c|c|c|c|c|}
\hline Hybrids & Nhc & $\mathrm{Ci}$ & Dhc & $\mathrm{TCi}$ \\
\hline L4XL8 & $60434 a$ & $85239 a$ & $128033 \mathrm{a}$ & $273706 \mathrm{a}$ \\
\hline L5XL7 & $46131 \mathrm{ab}$ & $69737 \mathrm{ab}$ & $101133 \mathrm{ab}$ & $217001 \mathrm{ab}$ \\
\hline L7XL8 & $44040 \mathrm{abc}$ & $59911 \mathrm{bcd}$ & 87509 a-d & $191459 \mathrm{bc}$ \\
\hline L6XL7 & 28718 b-f & 60826 bcd & 91432 a-d & 180976 bcd \\
\hline L3XL6 & $26075 c-g$ & $64235 \mathrm{bc}$ & 89133 a-d & $179442 \mathrm{~b}-\mathrm{e}$ \\
\hline L2XL7 & $36186 \mathrm{~d}-\mathrm{g}$ & $61787 \mathrm{bcd}$ & 78061 a-e & $176034 \mathrm{~b}-\mathrm{e}$ \\
\hline L2XL3 & $21923 \mathrm{~d}-\mathrm{g}$ & 41806 e-i & $93939 \mathrm{abc}$ & 157667 b-f \\
\hline L4XL7 & 29447 b-e & 51660 cde & 75907 b-f & $157013 \mathrm{~b}-\mathrm{f}$ \\
\hline L3XL7 & $22888 \mathrm{~d}-\mathrm{g}$ & 46732 def & $75319 \mathrm{~b}-\mathrm{f}$ & $144939 \mathrm{c}-\mathrm{g}$ \\
\hline L4XL6 & $26063 \mathrm{c}-\mathrm{g}$ & $46615 \mathrm{~d}-\mathrm{g}$ & $62797 \mathrm{~b}-\mathrm{f}$ & $135475 c-g$ \\
\hline L2XL8 & $22851 \mathrm{~d}-\mathrm{g}$ & $37652 \mathrm{e}-\mathrm{k}$ & $73920 \mathrm{~b}-\mathrm{f}$ & $134422 \mathrm{c}-\mathrm{g}$ \\
\hline L3XL8 & $21657 \mathrm{~d}-\mathrm{g}$ & $36610 \mathrm{e}-\mathrm{k}$ & $74932 \mathrm{~b}-\mathrm{f}$ & $133198 \mathrm{c}-\mathrm{g}$ \\
\hline L4XL5 & $26743 c-g$ & $36433 \mathrm{e}-\mathrm{k}$ & $69892 \mathrm{~b}-\mathrm{f}$ & $133069 \mathrm{c}-\mathrm{g}$ \\
\hline L2XL5 & $18623 \mathrm{~d}-\mathrm{g}$ & $42752 \mathrm{e}-\mathrm{h}$ & $65787 \mathrm{~b}-\mathrm{f}$ & 127162 d-h \\
\hline Grajales St. & $18521 \mathrm{~d}-\mathrm{g}$ & 36429 e-k & 71829 b-f & $126778 \mathrm{~d}-\mathrm{h}$ \\
\hline L5XL8 & $22091 \mathrm{~d}-\mathrm{g}$ & $31209 \mathrm{f}-\mathrm{l}$ & $68631 \mathrm{~b}-\mathrm{f}$ & $121932 \mathrm{~d}-\mathrm{i}$ \\
\hline L1XL7 & $23816 \mathrm{~d}-\mathrm{g}$ & $40475 e-j$ & $55043 \mathrm{~b}-\mathrm{f}$ & $119334 \mathrm{e}-\mathrm{i}$ \\
\hline L1XL3 & $12782 \mathrm{efg}$ & $30426 \mathrm{~g}-1$ & $61393 \mathrm{~b}-\mathrm{f}$ & $104601 \mathrm{f}-\mathrm{i}$ \\
\hline L1XL4 & $23791 \mathrm{~d}-\mathrm{g}$ & $34925 \mathrm{f}-1$ & 41524 def & $100240 \mathrm{f}-\mathrm{i}$ \\
\hline L6XL8 & $18860 \mathrm{~d}-\mathrm{g}$ & 30172 h-l & $45185 \mathrm{cdef}$ & 94217 ghi \\
\hline L1XL2 & $21516 \mathrm{~d}-\mathrm{g}$ & $36861 \mathrm{e}-\mathrm{k}$ & 35417 ef & 93794 ghi \\
\hline L3XL5 & $9962 \mathrm{fg}$ & $25699 \mathrm{i}-1$ & $52124 \mathrm{~b}-\mathrm{f}$ & 87785 ghi \\
\hline L3XL4 & $10411 \mathrm{fg}$ & $23766 \mathrm{kl}$ & $35822 \mathrm{ef}$ & $69999 \mathrm{hi}$ \\
\hline L1XL5 & $18291 \mathrm{~d}-\mathrm{g}$ & $21954 \mathrm{kl}$ & $27062 \mathrm{f}$ & $67306 \mathrm{hi}$ \\
\hline L2XL4 & $13704 \mathrm{efg}$ & 188721 & 31795 ef & $64371 \mathrm{i}$ \\
\hline L1XL6 & $9351 \mathrm{~g}$ & $24749 \mathrm{jkl}$ & $27737 \mathrm{~g}$ & $61837 \mathrm{i}$ \\
\hline MDSH & 18986 & 16254 & 50210 & 60499 \\
\hline
\end{tabular}

Note: The concentration of capsaicinoids is expressed in SHU (Scoville Heat Units). Means with the same letter within columns do not show significant statistical differences (Tukey's test, $\mathrm{p} \leq 0.05$ ).

HSMD: Honest significant minimum difference. 
'Canario' (C. pubescens) reported values of $1.9 \mathrm{mg} 100 \mathrm{~g}^{-1}$

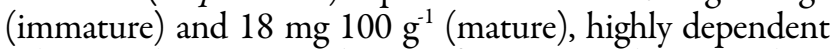
values on the variety and stage of maturity at harvest. These results surpass those found in other types of pepper such as habanero (C. chinense Jacq.) (281.73 mg $\left.100 \mathrm{~g}^{-1}\right)$ (Segura et al., 2013; Teodoro et al., 2013) and bell pepper (C. annum

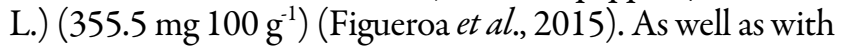
other vegetable species such as husk tomato (Physalis ixocarpa Brot, ex Horm) (3.31 mg $100 \mathrm{~g}^{-1}$ ) (Cruz-Álvarez et al., 2012) and carrot (Daucus carota L.) (3.5 mg $100 \mathrm{~g}^{-1}$ ) (Datt et al., 2012). In this sense, these results allow to assert that these materials can be useful for commercial use and be an important source of vitamin $\mathrm{C}$ and help to be a preventive factor for cancer by inhibiting the synthesis of $\mathrm{N}$ nitroso compounds in the stomach and stimulating the immune system (Cruz-Pérez et al., 2007; Datt et al., 2012).

\section{Total carotenoids}

Color changes (salmon, yellow, orange, red and brown) in the chili fruit are closely related to the accumulation of specific mixtures of carotenoids (capsanthin, $\alpha, \beta$-carotene, zeaxanthin, lutein and $\beta$-cryptoxanthin) (Wahyuni et al., 2013; Hwang-Sung et al., 2015) and its concentration varies depending on the cultivar and edaphoclimatic conditions prevailing during its growth and development (AgostiniCosta et al., 2017). This compound presented significant variation $(\mathrm{P} \leq 0.05)$ between hybrids, where L2XL3 stood

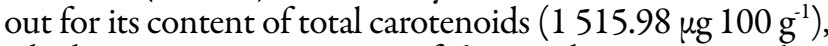
which represents a variation of $62 \%$ with respect to L6X7 $\left(426.56 \mu \mathrm{g} 100 \mathrm{~g}^{-1}\right)$ with the lowest value (Table 1$)$. What is found in this study contrasts with that pointed out by SunHwa et al. (2007) for yellow fruits of C. pubescens (1 $950 \mu \mathrm{g}$ $\left.100 \mathrm{~g}^{-1}\right)$, C. baccatum $\left(1600 \mu \mathrm{g} 100 \mathrm{~g}^{-1}\right)$ and C. chinense Jacq. (2 $000 \mu \mathrm{g} 100 \mathrm{~g}^{-1}$ ), but similar to those obtained by Rodríguez-Uribe et al. (2012) in five types of chili ( $C$. annuum) with orange-yellow fruits (233 to $1615 \mu \mathrm{g} 100$ $\left.\mathrm{g}^{-1}\right)$. Values of 1000 to $1260 \mu \mathrm{g} 100 \mathrm{~g}^{-1}$ are reported in habanero chili fruits ( $C$. chinense Jacq.) grown in Yucatan, Mexico, with different colorations (orange, red, yellow and brown) by Segura et al. (2013), which are similar to those found in L1XL6, L2XL8, L5XL7 and L6XL8 ( 1 270.87, 1 108.74, 1273.07 and $1248.29 \mu \mathrm{g} 100 \mathrm{~g}^{-1}$, respectively.) Additionally, Agostini-Costa et al. 2017) when evaluating different varieties of jalapeño ( $C$. annuum L.) and habanero peppers cultivated in Brazil, and with red and yellow tones, they report that they did not find variation regarding to the content of total carotenoids with values of $304 \pm 92 \mathrm{mg} \mathrm{g}^{-1}$; according to these same authors, this variation is strongly influenced by the stress caused by the high light exposure during its growth and development, where the variety plays an important role (Wahyuni et al., 2013).

\section{Total soluble solids}

The accumulation of solutes during the maturation process is one of the parameters with greater precision and reliability when used as a harvest index in fruits and vegetables (Sánchez-Sánchez et al., 2010), because its determination is rapid, relatively low cost and it correlates directly with flavour (Beckles, 2012). Among the manzano hot pepper genotypes, there was statistical variation regarding the concentration of TSS (Table 2 ), where the hybrid L2XL7 was higher $(\mathrm{P} \leq 0.05)\left(7.40^{\circ} \mathrm{Brix}\right)$, without exceeding that observed in $\mathrm{L} 4 \mathrm{Xl} 7$ (7.30 $\left.{ }^{\circ} \mathrm{Brix}\right)$ In addition, the values found were $19.86 \%$ higher in relation to the commercial variety $\left(5.93^{\circ} \mathrm{Brix}\right)$. In this sense, Navarro et al. (2006) report 6.99 and $4.92{ }^{\circ}$ Brix in fruits with 50 and $100 \%$ red hue. On the other hand, Figueroa et al. (2015) indicate data with a range of values between 8.1 and 9.5 ${ }^{\circ}$ Brix in red peppers with different color tones. Additionally, Fox et al. (2005) reported values of 6.9 and $7.9{ }^{\circ}$ Brix in fruits with ripeness of pepper consumption 'Robusta' and two harvest dates. The process of fruit maturation involves a series of changes related to respiration, degradation of compound such as chlorophyll and substances involved in obtaining cellular energy (Beckles, 2012), and its variation is widely correlated to its nutritional management (Yamamoto et al., 2013), variety and state of maturity (Jiménez et al., 2013).

\section{Titratable acidity}

The characteristic flavor of each horticultural product must not only be associated as a consequence of the presence of sugars (sucrose, glucose, galactose and fructose) (Giovannoni, 2007), but also to the accumulation of organic acids (citrate and malate) (Beckles, 2012). The acidity data of the fruits expressed as a function of the prevailing organic acid (citric acid) are shown in Table 2, which fluctuated between 0.32 and $0.45 \%$ with little variation among genotypes, where L4XL7 was the most outstanding and with the exception of L2XL7 and L2XL3, this hybrid showed a similar behavior to the rest of the materials, including the control. When comparing these values with those reported for this species and other types of chili, these surpass the $0.052 \%$ found in fruits of the variety 'Puebla' of manzano hot pepper (Espinoza-Torres et al., 2010); but they are similar to those reported by Salinas et al. (2010) for four types of Amashito peppers, whose values ranged between 0.30 and $0.40 \%$ citric acid, as well as those reported by Fox et al. (2005) in red bell pepper fruits harvested on two dates ( 0.29 and $0.32 \%$ citric acid). On the other hand, Figueroa et al. (2015) when evaluating six commercial varieties and three fruit colorations: 'Magno' (orange), 'Moonset' (yellow), 'California' (yellow), 'Triple 4' (red), 'Triple Star' (red) and 'Viper' (red), report a maximum value of $0.67 \%$ in red fruits. In others species such as tomato (Solanum lycopersicum L.) Cheema et al. (2014) when performing hexanal applications and in combination of controlled atmospheres, they report values of 0.42 to $0.57 \%$, similar to those found in L4XL7 and L4XL8. The way in which the data of titratable acidity behaved, could also be linked to the $\mathrm{pH}$ of the fruits which also did not show significant variation (data not shown), which are widely correlated with the state of maturity during its evaluation (Figueroa et al., 2015), which in this work, the fruits evaluated were harvested with a similar state of maturity (consumption maturity). Authors such as Espinoza-Torres et al. (2010) and Beckles (2012) indicate may be linked to a decrease in the concentration of organic acids in ionized form and phenolic compounds in plant tissue. 
Table 2. Concentration of vitamin C, total carotenoids, total soluble solids and titratable acidity evaluated in manzano hot pepper fruits grown in greenhouse

\begin{tabular}{|c|c|c|c|c|}
\hline Hybrids & $\begin{array}{c}\mathrm{VC} \\
\left(\mathrm{mg} \mathrm{l} 100 \mathrm{~g}^{-1}\right)\end{array}$ & $\begin{array}{c}\text { TC } \\
\left(\mu \mathrm{g} 100 \mathrm{~g}^{-1}\right)\end{array}$ & $\begin{array}{c}\text { TSS } \\
\left({ }^{\circ} \text { Brix }\right)\end{array}$ & $\begin{array}{c}\text { TA } \\
\text { (\% citric acid) }\end{array}$ \\
\hline L4XL8 & $679.90 \mathrm{ab}$ & $537.03 \mathrm{bc}$ & $6.52 \mathrm{a}-\mathrm{f}$ & $0.44 \mathrm{ab}$ \\
\hline L5XL7 & $776.99 \mathrm{ab}$ & $1273.07 \mathrm{abc}$ & $6.95 \mathrm{a}-\mathrm{d}$ & $0.39 a b c$ \\
\hline L7XL8 & $744.63 \mathrm{ab}$ & $1428.43 \mathrm{ab}$ & $6.65 \mathrm{a}-\mathrm{f}$ & $0.40 a b c$ \\
\hline L6XL7 & $615.18 \mathrm{ab}$ & $426.56 c$ & $6.55 \mathrm{a}-\mathrm{f}$ & $0.39 a b c$ \\
\hline L3XL6 & $615.18 \mathrm{ab}$ & $1355.07 \mathrm{abc}$ & $6.43 \mathrm{a}-\mathrm{f}$ & $0.39 a b c$ \\
\hline L2XL7 & $485.73 b$ & $565.62 \mathrm{abc}$ & $7.40 \mathrm{a}$ & $0.32 \mathrm{bc}$ \\
\hline L2XL3 & $679.90 \mathrm{ab}$ & $1515.98 \mathrm{a}$ & $6.62 \mathrm{a}-\mathrm{f}$ & $0.32 b c$ \\
\hline L4XL7 & $679.90 \mathrm{ab}$ & $680.87 \mathrm{abc}$ & $7.30 \mathrm{ab}$ & $0.45 \mathrm{a}$ \\
\hline L3XL7 & $744.63 \mathrm{ab}$ & $700.53 \mathrm{abc}$ & $6.88 \mathrm{a}-\mathrm{e}$ & $0.34 a b c$ \\
\hline L4XL6 & $776.99 \mathrm{ab}$ & $508.08 \mathrm{bc}$ & $5.80 \mathrm{f}$ & $0.35 \mathrm{abc}$ \\
\hline L2XL8 & $582.82 \mathrm{ab}$ & $1108.74 \mathrm{abc}$ & $6.15 c-f$ & $0.33 a b c$ \\
\hline L3XL8 & $744.63 \mathrm{ab}$ & $885.39 a b c$ & $5.73 \mathrm{f}$ & $0.38 \mathrm{abc}$ \\
\hline L4XL5 & $744.63 \mathrm{ab}$ & $714.86 \mathrm{abc}$ & $6.32 \mathrm{c}-\mathrm{f}$ & $0.35 a b c$ \\
\hline L2XL5 & 809.35 a & $860.39 \mathrm{abc}$ & $6.52 \mathrm{a}-\mathrm{f}$ & $0.32 b c$ \\
\hline Grajales St. & $647.54 \mathrm{ab}$ & $638.07 \mathrm{abc}$ & $5.93 \mathrm{ef}$ & $0.35 \mathrm{abc}$ \\
\hline L5XL8 & $615.18 \mathrm{ab}$ & $853.20 a b c$ & $6.00 \mathrm{def}$ & $0.41 \mathrm{abc}$ \\
\hline L1XL7 & $485.73 \mathrm{~b}$ & $679.97 \mathrm{abc}$ & $7.10 a b c$ & $0.39 a b c$ \\
\hline L1XL3 & $518.09 \mathrm{ab}$ & $648.29 \mathrm{abc}$ & $6.10 \mathrm{def}$ & $0.41 \mathrm{abc}$ \\
\hline L1XL4 & $550.45 \mathrm{ab}$ & $811.92 \mathrm{abc}$ & $6.95 \mathrm{a}-\mathrm{d}$ & $0.36 \mathrm{abc}$ \\
\hline L6XL8 & $582.82 \mathrm{ab}$ & $1248.29 \mathrm{abc}$ & $6.00 \mathrm{def}$ & $0.33 a b c$ \\
\hline L1XL2 & $582.82 \mathrm{ab}$ & $472.09 \mathrm{bc}$ & $6.33 \mathrm{~b}-\mathrm{f}$ & $0.34 a b c$ \\
\hline L3XL5 & $582.82 \mathrm{ab}$ & $987.78 \mathrm{abc}$ & $6.05 \mathrm{def}$ & $0.35 a b c$ \\
\hline L3XL4 & $744.63 \mathrm{ab}$ & $862.56 \mathrm{abc}$ & $7.08 \mathrm{abc}$ & $0.34 a b c$ \\
\hline L1XL5 & $647.54 \mathrm{ab}$ & $565.45 \mathrm{abc}$ & $6.30 \mathrm{c}-\mathrm{f}$ & $0.38 \mathrm{abc}$ \\
\hline L2XL4 & $647.54 \mathrm{ab}$ & $672.78 \mathrm{abc}$ & $6.32 \mathrm{c}-\mathrm{f}$ & $0.37 \mathrm{abc}$ \\
\hline L1XL6 & $615.18 \mathrm{ab}$ & $1270.87 \mathrm{abc}$ & $6.37 \mathrm{~b}-\mathrm{f}$ & $0.41 \mathrm{abc}$ \\
\hline HSMD & 298.01 & 298.01 & 0.98 & 0.117 \\
\hline
\end{tabular}

Note: Means with the same letter within columns do not show significant statistical differences (Tukey's test, $\mathrm{p} \leq 0.05$ ).

HSMD: Honest significant minimum difference.

\section{Firmness}

The quantitative expression of the structural characteristics of the cell wall between harvested products constitutes one of the attributes of quality most appreciated by the consumer (Giovannoni, 2007), which is why, among the various plant breeding programs, this parameter it is one of the main selection characters (Figueroa et al., 2015). In this study, the evaluated hybrids showed values of significant firmness $(\mathrm{P} \leq 0.05)$ (Table 4$)$, with L7XL8 showing fruits with an average firmness value of $2.31 \mathrm{~N}$, nevertheless, their behavior was similar to $84.61 \%$ (22 materials) of the genotypes evaluated, including the commercial variety $(2.08$ $\mathrm{N})$. These results show a clear contrast with what was found by Figueroa et al. (2015) in bell peppers, which, when harvested with different coloration, their firmness values fluctuated between 12.60 and $24.63 \mathrm{~N}$.

Additionally, they also surpass those reported in manzano hot pepper by Espinoza-Torres et al. (2010) who, when evaluating the effect of packaging with different storage conditions, found values between 17.65 and 33.34 $\mathrm{N}$. With respect to this behavior, it is of prime interest to indicate that this quality parameter is directly associated with the degree of maturity of the fruit at the time of harvest (Hwang-Sung et al., 2015), additionally, due to its morphological and physiological characteristics, once separated from the mother plant, it loses turgor as a result of the transpiration process (Jiménez et al., 2013).

\section{Color}

The manzano hot pepper fruit is consumed when the coloration of its epidermis has changed to a yellowish hue without the presence of green stripes (Meckelmann et al., 2015), and it is the first aspect evaluated by the consumer, so this quality parameter is of vital importance in postharvest (Espinosa-Torres and Ramírez-Abarca, 2016; Tortoe et al., 2016). Among the color components evaluated, no statistical variation was found with respect to brightness (L) and hue (hue) (Table 4), however, the chromaticity that 
Table 3. Firmness and color (brightness, purity and color tone) evaluated in manzano hot pepper fruits grown in greenhouse

\begin{tabular}{|c|c|c|c|c|}
\hline \multirow{2}{*}{ Hybrids } & \multirow{2}{*}{$\mathrm{F}$} & \multicolumn{3}{|c|}{ Color } \\
\hline & & $\mathrm{L}$ & Chroma & Hue $\left(^{\circ}\right)$ \\
\hline L4XL8 & $1.96 \mathrm{bc}$ & $38.72 \mathrm{a}$ & $44.97 \mathrm{~b}$ & $71.89 \mathrm{a}$ \\
\hline L5XL7 & $2.04 \mathrm{abc}$ & $39.30 \mathrm{a}$ & $47.50 \mathrm{ab}$ & $66.44 \mathrm{a}$ \\
\hline L7XL8 & $2.31 \mathrm{a}$ & $37.50 \mathrm{a}$ & $72.96 \mathrm{a}$ & $77.38 \mathrm{a}$ \\
\hline L6XL7 & $2.08 \mathrm{abc}$ & $44.17 \mathrm{a}$ & $46.49 \mathrm{~b}$ & $75.46 \mathrm{a}$ \\
\hline L3XL6 & $2.09 a b c$ & $42.57 \mathrm{a}$ & $53.09 \mathrm{ab}$ & $72.24 \mathrm{a}$ \\
\hline L2XL7 & $2.09 \mathrm{abc}$ & $42.74 \mathrm{a}$ & $59.04 \mathrm{ab}$ & $66.32 \mathrm{a}$ \\
\hline L2XL3 & $2.17 \mathrm{abc}$ & $40.41 \mathrm{a}$ & $42.49 \mathrm{~b}$ & $59.77 \mathrm{a}$ \\
\hline L4XL7 & $2.03 \mathrm{abc}$ & $43.64 \mathrm{a}$ & $48.77 \mathrm{ab}$ & $73.01 \mathrm{a}$ \\
\hline L3XL7 & $2.23 \mathrm{ab}$ & $42.32 \mathrm{a}$ & $57.74 \mathrm{ab}$ & $70.31 \mathrm{a}$ \\
\hline L4XL6 & $2.11 \mathrm{abc}$ & $36.57 \mathrm{a}$ & $45.70 \mathrm{~b}$ & $69.75 \mathrm{a}$ \\
\hline L2XL8 & $2.09 \mathrm{abc}$ & $37.22 \mathrm{a}$ & $47.19 \mathrm{ab}$ & $44.61 \mathrm{a}$ \\
\hline L3XL8 & $2.10 \mathrm{abc}$ & $38.26 \mathrm{a}$ & $56.19 \mathrm{ab}$ & $77.82 \mathrm{a}$ \\
\hline L4XL5 & $2.15 \mathrm{abc}$ & $38.36 \mathrm{a}$ & $45.27 \mathrm{~b}$ & $67.88 \mathrm{a}$ \\
\hline L2XL5 & $2.07 \mathrm{abc}$ & $40.74 \mathrm{a}$ & $47.90 \mathrm{ab}$ & $79.70 \mathrm{a}$ \\
\hline Grajales St. & $2.08 \mathrm{abc}$ & $38.22 \mathrm{a}$ & $48.06 \mathrm{ab}$ & $77.35 \mathrm{a}$ \\
\hline L5XL8 & $2.06 \mathrm{abc}$ & $41.82 \mathrm{a}$ & $50.89 \mathrm{ab}$ & $73.66 \mathrm{a}$ \\
\hline L1XL7 & $2.07 \mathrm{abc}$ & $41.66 \mathrm{a}$ & $54.35 \mathrm{ab}$ & $73.18 \mathrm{a}$ \\
\hline L1XL3 & $2.06 \mathrm{abc}$ & $39.35 \mathrm{a}$ & $45.16 \mathrm{~b}$ & $68.31 \mathrm{a}$ \\
\hline L1XL4 & $1.99 \mathrm{bc}$ & $37.69 a$ & $37.96 \mathrm{~b}$ & $74.31 \mathrm{a}$ \\
\hline L6XL8 & $2.01 \mathrm{abc}$ & $38.46 \mathrm{a}$ & $45.69 \mathrm{~b}$ & $81.01 \mathrm{a}$ \\
\hline L1XL2 & $2.04 \mathrm{abc}$ & $35.50 \mathrm{a}$ & $39.58 \mathrm{~b}$ & $66.53 \mathrm{a}$ \\
\hline L3XL5 & $2.11 \mathrm{abc}$ & $38.71 \mathrm{a}$ & $43.92 \mathrm{~b}$ & $65.70 \mathrm{a}$ \\
\hline L3XL4 & $2.07 a b c$ & $40.01 \mathrm{a}$ & $42.82 \mathrm{~b}$ & $61.10 \mathrm{a}$ \\
\hline L1XL5 & $1.92 \mathrm{c}$ & $39.69 a$ & $44.65 \mathrm{~b}$ & $66.09 \mathrm{a}$ \\
\hline L2XL4 & $2.08 \mathrm{abc}$ & $36.56 \mathrm{a}$ & $39.01 \mathrm{~b}$ & $73.61 \mathrm{a}$ \\
\hline L1XL6 & $1.88 \mathrm{c}$ & 34.66 & $44.47 \mathrm{~b}$ & $53.92 \mathrm{a}$ \\
\hline HSMD & 0.307 & 10.318 & 26.404 & 38.464 \\
\hline
\end{tabular}

Note: Means with the same letter within columns do not show significant statistical differences (Tukey's test, $\mathrm{p} \leq 0.05$ ).

HSMD: Honest significant minimum difference.

refers to the purity of the characteristic color (Tortoe et al., 2016), statistically highlights $(\mathrm{P} \leq 0.05)$ the L7XL8 hybrid with 72.96, however, it is similar to that shown by L5XL7, L3XL6, L2XL7, L4XL7, L3XL7, L2XL8, L3XL8, L2XL5, 'Grajales St.', L5XL8 and L1XL7 whose values fluctuated between 47.19 and 59.04 and correspond to fruits with intense yellow color and representing $42.30 \%$ of the evaluated materials. In contrast, Moreno-Pérez et al. (2006) when evaluating mature fruits of 162 collections (plants) of native chili guajillo (C. annuum L.), coming from the states of Jalisco, Zacatecas and Durango, Mexico, indicate maximum values of 34.30 .

On the other hand, Figueroa et al. (2015) report similar data that ranged between 34.17 and 48.96, in fruits of bell pepper varieties with different color, where varieties with orange ('Magno') and yellow ('California' and 'Moonset') tones presented the higher values of chromaticity with 48.96, 47.96 and 45.94, respectively. In this sense, the chili fruit is characterized by a non-climacteric maturation pattern, which is why many processes are not associated with the synthesis and action of ethylene (Bo and Carpizo,
2015), but it is strongly influenced by postharvest handling conditions (Espinoza-Torres et al., 2010), resulting in gradual degradation and the accumulation of secondary compounds (carotenoids) in the pericarp chromoplasts (Vera-Guzmán et al., 2011).

\section{Conclusions}

Differences were found in the content of capsaicinoids (dihydrocapsaicin, capsaicin and nordihydrocapsaicin) and $52 \%$ of the evaluated hybrids exceeded the control. On the other hand, L2XL5 and L2XL3 had the highest content of vitamin $\mathrm{C}$ and total carotenoids, respectively; where in the same way L2XL7 and L4Xl7 stood out for their concentration of total soluble solids. Additionally, L7XL8 was the one of greater firmness and purity of color. Manzano hot pepper hybrids presented fruits with outstanding physicochemical characteristics, which could be important from the nutritional point of view, and susceptible to commercial use or genetic improvement. 
126

\section{Acknowledgements}

The authors thank the Autonomous University of Chapingo (UACh) for the facilities granted and the National Council for Science and Technology of Mexico (CONACYT) for the financial support for carrying out this research.

\section{References}

Agostini-Costa TS, Silva GI, Martins PLA, Becke SFJ, Costa RCS (2017). Carotenoid and total vitamin $\mathrm{C}$ content of peppers from selected Brazilian cultivars. Journal of Food Composition and Analysis 57:73-79.

AOAC (1995). Association of Official Analytical Chemists. Official Method 995.03. Capsaicinoids in capsicums and their extractives liquid chromatographic method. Retrieved 2017 March 04 from http://eoma.aoac.org.

AOAC (1990). Association of Official Analytical Chemists. Official Methods and Analysis (14th ed). Association of Official Analytical Chemists Inc. Arlington, Virginia.

Beckles DM (2012). Factors affecting the postharvest soluble solids and sugar content of tomato (Solanum lycopersicum L.) fruit. Postharvest Biology and Technology 63(1):129-140.

Bo ML, Carpizo GC (2015). Pollen phenotyping and performance in rocoto chili (Capsicum pubescens Ruiz et Pav, Solanaceae). Grana 54(1):37-44.

Cheema A, Padmanabhan P, Subramanian J, Blom T, Paliyath G (2014). Improving quality of greenhouse tomato (Solanum lycopersicum $\mathrm{L}$.) by pre- and postharvest applications of hexanal-containing formulations. Postharvest Biology and Technology 95:13-19.

Collins DM, Mayer WL, Bosland WP (1995). Improved method for quantifying capsaicinoids in Capsicum using high-performance liquid chromatography. HortScience 30(1):137-139.

Cruz-Álvarez O, Martínez-Damián MT, Rodríguez-PérezJE, Colinas-León MT, Moreno-PérezEC (2012). Conservación poscosechade tomate de cáscara (Physalis ixocarpa Brot. ex Horm.) con y sin cáliz [Postharvest conservation of husk tomato (Physalis ixocarpa Brot. Ex. Horm.) with and without calyx]. Revista Chapingo Serie Horticultura 18(3):333344.

Cruz-Pérez AB, González-Hernández VA, Soto-Hernández RM, Gutiérrez-Espinoza MA, Gerdea-Béjar AA, Pérez-Grajales M (2007). Capsaicinoides. vitamina $\mathrm{C}$ y heterosis durante el desarrollo del fruto de chile Manzano [Capsaicinoids, vitamin $\mathrm{c}$ and heterosis during fruit development of manzano hot pepper]. Agrociencia 41(6):627-635.

Datt SK, Karki S, Singh N, Attri S (2012). Chemical composition, functional properties and processing of carrot-a review. Journal of Food Science and Technology 49(1):22-32.

De Aguiar AC, Pereira CJ, Fernandez BG, Teixeira GH, Martínez J (2016). Comparative study of capsaicinoid composition in capsicum peppers grown in Brazil. International Journal of Food Properties 19(6):12921302.

Espinosa-Torres LE, Ramírez-Abarca O (2016). Rentabilidad de chile manzano (Capsicum pubescens R Y P) producido en invernadero en Texcoco, Estado de México [Profitability chile apple (Capsicum pubescens RY P) produced in greenhouses in Texcoco, State of Mexico].
Revista Mexicana de Ciencias Agrícolas 7(2):325-335.

Espinosa-Torres LE, Ramírez-Abarca O, Figueroa-Hernández E (2014). Tipología del mercado de chile manzano en el Estado de México [Typology manzano hot pepper markets in the State of Mexico]. DebateEconómico3(2):143-163.

Espinosa-Torres LE, Pérez-Grajales M, Martínez-Damián MT, CastroBrindis R, Barrios-Puente G (2010). Efecto de empaques y temperaturas en chile manzano (Capsicum pubescens Ruíz y Pavón) [Effect of packaging and postharvest storage temperatures on manzano hot peppers (Capsicum pubescens Ruíz \& Pavón]. Revista Chapingo Serie Horticultura 16(2):115-121.

Figueroa CIE, Martínez DMT, Rodríguez PJE, Cruz AO, Colinas LBMT, Valle GS, Ramírez RSP (2015). Capacidad antioxidante en variedades de pimiento morrón (Capsicum annum L.) [Antioxidant capacity in sweet pepper (Capsicum annumm L.) varieties]. Interciencia 40(10):696703.

Fox AJ, Del Pozo-Insfran D, Lee JH, Sargent SA, Talcott ST (2005). Ripening-induced chemical and antioxidant changes in bell peppers as affected by harvest maturity and postharvest ethylene exposure. HortScience 40(3):732-736.

Giovannoni JJ (2007). Fruit ripening and its manipulation. In: Gan S (Ed). Senescence processes in plants: annual plants reviews. Blackwell PublishingLtd,New Yorkpp 278-295.

Hwang-Sung M, Kil-Su J, Ji-Eun H, Su-Gyeong J, Byung-Soo K (2015). Horticultural and chemical quality characterization of accessions selected from four species of Capsicum. Horticulture, Environment and Biotechnology 56(1):5466.

Islam AM, Sundar SS, Sinha P, Singh NM, Neog B, Bhushan TS (2015). Variability in capsaicinoid content in different landraces of Capsicum cultivated in north-eastern India. Scientia Horticulturae 183:66-71.

Jiménez LJ, López EJ, Huez LMA, García LAM, Soto OR, Escoboza GLF (2013). Postharvest quality and shelf life of green pepper (Capsicum annuum L.) grown under open-field and greenhouse conditions. IDESIA 31(4):35-41.

Lichtenhaler KH (1987). Chlorophylls and carotenoids: Pigments of photosynthetic biomembranes. In: Packer L, Douce R (Eds). Methods in enzymology. Academic Press Inc, New York pp 350-382.

Meckelmann WS, Jansen C, Riegel WD, Zonneveld M, Rios L, Peña K, Mueller-Seitz E (2015). Phytochemicals in native Peruvian Capsicum pubescens (Rocoto). European Food Research and Technology 241(6):817-825.

Minolta K (2007). Precise Color Communication. Color control from perception to instrumentation. Japan, Konica Minolta Sensing, Inc. Retrieved 2017 December 12 from https://www.konicaminolta. com/instruments/knowledge/color/pdf/color_communication.pdf.

Moreno-PérezEC, Martínez-Damián MT, Reyes-LópezD, Pérez-Mercado CA, Peña-Lomelí A, Espinosa-Robles P (2006). Intensidad de color y contenido de antocianinas en chile guajillo (Capsicum annuum L.) [Color intensity and anthocyanins content in chilli guajillo (Capsicum annumum L.)]. Revista Chapingo Serie Horticultura 17(1):135-140.

Navarro MJ, Flores C, Garrido C, Martínez V (2006). Changes in the contents of antioxidant compounds in pepper fruits at different ripening stages. as affected by salinity. Food Chemistry 96(1):66-73. 
Orellana-Escobedo L, García-Amezquita LE, Olivas GI, Ornelas-Paz JJ, Sepúlveda DR (2013). Capsaicinoids content and proximate composition of Mexican chili peppers (Capsicum spp.) cultivated in the State of Chihuahua. CyTA-Journal of Food 11(2):179-184.

Pérez GM, Castro BR (1998). Guía técnica para la producción intensiva de chile manzano [Technical guide for the intensive production of manzano hot pepper]. Universidad Autónoma Chapingo. Texcoco, Mexico.

Pérez GM, Castro BR (2012). El chile Manzano [The manzano hot pepper]. Universidad Autónoma Chapingo. Texcoco, Mexico.

Rodríguez-Burruezo A, González-Mas MC, Nuez F (2010). Carotenoid composition and vitamin A value in aji (Capsicum baccatum $\mathrm{L}$.) and rocoto (C.pubescens R \& P.), 2 pepper species from the Andean Region. Journal of FoodScience 75(8):S446-53.

Rodríguez-Uribe L, Guzmán I, Rajapakse W, Richinis RD, O’Conell MA (2012). Carotenoid accumulation in orange-pigmented Capsicum annuum fruit. regulated at multiple levels. Journal of Experimental Botany 63(1):517-526.

Salinas HRM, Lievano LEA, Ulín-Montejo F, Mercado JN, Petit JD (2010). Caracterización morfológica y cambios durante la vida postcosecha de cuatro tipos de chile Amashito (Casicum annuum L.) variedad Glabriusculum (Dunal) Heiser \& Pickersgill [Morphological characterization and postharvest changes of four Amashito chili types (Capsicum annuum L.) variety Glabriusculum (Dunal) Heiser \& Pickersgill]. Revista Iberoamericana de Tecnología Postcosecha 11(1):92-100.

Sánchez-Sánchez $\mathrm{H}$, González-Hernández VA, Cruz-Pérez AB, PérezGrajales M, Gutiérrez-Espinosa MA, Gardea-Béjar AA, Gómez-Lim MA (2010). Herencia de capsaicinoides en chile Manzano (Capsicum pubescens R y P.) [Inheritance of capsaicinoids in manzano hot chili pepper (Capsicum pubescens R and P.)].Agrociencia 44(6):656-665.

SAS Institute Inc (2003). Base SAS 9.1 Procedures Guide. Cary, NC: SAS Institute Inc.
Segura CMR, Ramirez GK, Moguel OY, Betancur AD (2013). Polyphenols, ascorbic acid and carotenoids contents and antioxidant properties of habanero pepper (Capsicum chinense) fruit. Food and Nutrition Sciences 4:47-54.

Sun-Hwa H, Jung-BongK, Jong-Sug P, Shin-Woo L, Kang-Jin C (2007). A comparison of the carotenoid accumulation in Capsicum varieties that show different ripening colours: deletion of the capsanthin-capsorubin synthase gene is not a prerequisite for the formation of a yellow pepper. Journal of Experimental Botany 58(12):3135-3144.

Teodoro PAF, Alves BNR, Ribero BL, Reis K, Reifschneider BFJ, Fonseca NME, Silva PJ, Agostini-Costa T (2013). Vitamin C content in habanero pepper accessions (Capsicum chinense). Horticultura Brasileira 31(1):59-62.

Tortoe C, Toah AP, Essel M (2016). Physicochemical and colorimetric properties of green pepper (Capsicum annuum L.) puree. Annals. Food Science and Technology 17(1):172-178.

Vera-Guzmán AM, Chávez-Servia JL, Carrillo-Rodríguez JC, López GM (2011). Phytochemical evaluation of wild and cultivated pepper (Capsicum annuum $\mathrm{L}$ and C. pubescens Ruiz \& Pav.) from Oaxaca, México. Chilean Journal of Agricultural Research 71(4):578-585.

Vera-Guzmán, AM, Aquino-Bolaños EN, Heredia-García E, CarrilloRodríguez JC, Hernández-Delgado S, Chávez-Servia JL (2017). Flavonoid and capsaicinoid contents and consumption of mexican chili pepper (Capsicum annuum L.) landraces. In: Gonçalo CJ (Ed). Flavonoids - from biosynthesis to human health. InTechOpen, London pp $405-437$.

Wahyuni Y, Ballester AR, Sudarmonowati E, Bino RJ, Bovy GA (2013). Secondary metabolites of Capsicum species and their importance in the human diet. Journal of Natural Products 76:783-793.

Yamamoto S, Djarwaningsih T, Wiriadinata H (2013). Capsicum pubescens (Solanaceae) in Indonesia: its history, taxonomy, and distribution. Economic Botany 67(2):161-170. 